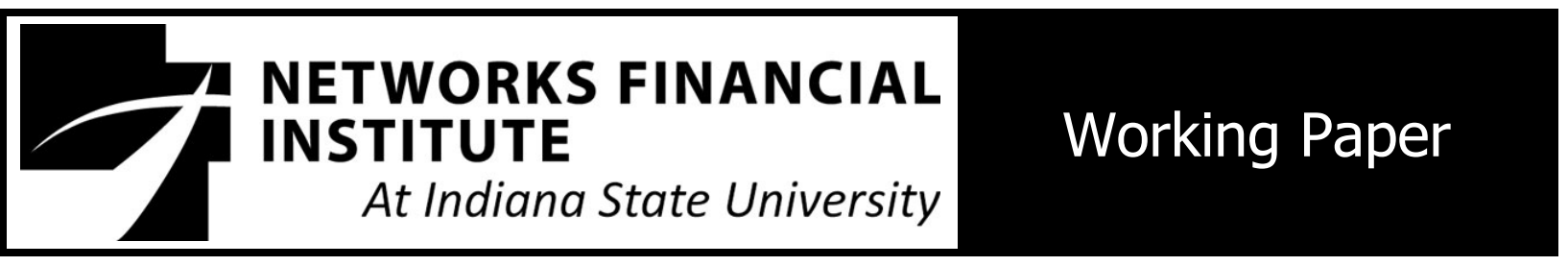

2019-WP-03 - July 2019

\title{
Trends in Financial Innovation: Evidence from Fintech Firms
}

\section{Omer Unsal and Blake Rayfield}

Abstract: In 1971, the patent for the Automated Teller Machine (ATM) was awarded to David Wetzel. While possibly not the first application of financial technology, since 1971 time, the innovation in the financial industry has grown beyond expectations. However, most studies in innovation ignore the financial sector altogether. In this study, we investigate financial technology firms and innovation. After identifying firms that are considered financial technology, we collect innovation outcomes such as patents and data breaches associated with those firms. We show that patent activity has enjoyed modest growth year over year, however firms still have challenges to overcome such as market risk and data security. This study serves as a perspective on financial technology. This paper is also forthcoming in the International Finance Review.

About the Authors: Omer Unsal is Assistant Professor of Finance at Merrimack College, Girard School of Business, 315 Turnpike Street, North Andover, MA 01845. Phone: (269) 5485524. Email: unsalo@merrimack.edu. Dr. Unsal's research is mainly focused on issues related to corporate governance. He investigates whether political contributions, lobbying spending and campaign donations contributes to shareholder wealth. He also researches various types of lawsuits including labor, patent, environmental, securities and antitrust cases to examine how legal challenges influence corporate governance practices.

Blake Rayfield is Assistant Professor of Finance at Indiana State University, Scott College of Business, Federal Hall, 30 N. 7th St., Terre Haute, IN 47809. Phone: (812) 237-8271. Email: blake.rayfield@indstate.edu. Dr. Rayfield is skilled in Python, Statistical Data Analysis, Data Analysis, Econometrics, and Big Data. He has authored and co-authored multiple peer-reviewed scientific papers and presented works at many national and International conferences.

Keywords: Financial Technology; Financial Innovation; Patents; Data Breach

JEL classification: 033; 016

The views expressed are those of the authors and do not necessarily reflect official positions of Networks Financial Institute. Please address questions regarding content the authors. This research did not receive any specific grant from funding agencies in the public, commercial, or not-for-profit sectors. The authors declare that they have no conflict of interest. NFI working papers and other publications are available on NFI's website (http://isunetworks.org). Click "Publications" 


\section{Introduction}

Innovation has been studied well in other sectors. Most studies focus on high-tech, high-growth sectors such as, Coad and Rao (2008) who investigate innovation in high-tech sectors and Unsal and Rayfield (2019) who investigate the role of innovation in the healthcare sector. However, little is known about the innovation and patenting activity of financial technology firms. Financial technology is a rapidly growing sector of finance. The innovation of financial technology, in particular, is disrupting business as usual practice in the finance industry. Practitioners and experts agree on the disruptiveness of the new technology synthesized by financial technology firms such as blockchain Cai (2018), crowdfunding Mollick (2014), and even something as simple as a search engine Hodge et al. (2004). In this study, we survey both the literature as well as do a preliminary investigation on the innovation and patenting activity of the financial technology industry.

Financial technology has become one of the newest trends in the finance sector. It has become a broad term to describe innovations in the financial sector generally related to the internet, technology, and mobile and cloud computing. Encouraging innovation is vital to the growth prospects of a firm. Fagerberg (2006) draws a distinction between invention as innovation "first occurrence of an idea for a new product or process, while innovation is the first attempt to carry it out into practice." For firms and society, innovation represents growth and advances. An investigation by Schueffel (2016) found the term "financial technology" to be broadly applied and to describe innovation in the financial sector, using semantic analysis the author finds the most common definition to be "a new financial industry that applies technology to improve financial activities." While this study helps define the ever-broadening term of financial technology, more importantly, it distinguishes the role of financial technology as an industry. 
Financial technology did not start as a sector, but rather a means to smooth the workflow of employees. In 1867 Edward Calahan created the first stock ticker. From meager beginnings, financial technology began with two of the most recognized innovations in the financial industry, the Electronic Calculating Punch (1948) and the Automated Teller Machine (ATM; 1971). These inventions were created to better compete in the financial industry. Both creations were patented, first the Electronic Calculating Punch in 1948 by IBM and the ATM in 1971 by David Wetzel (IEEE, 2016).

After the development of the processor the internet, the pace of technological growth in the finance quickly outpaced the industry. Today, financial technology firms are abundant and growing. In this study, we identify 120 publicly traded financial technology firms.

Inspired by the definition set forth by Schueffel (2016), we define Financial Technology firms as information technology, software, or research services firms, that describe themselves in their business description as working as or serving as financial institutions, banking, financial services, wealth management, finance, or payment services. In addition, due to data limitations, we primarily investigate publicly traded firms available in Compustat.

For financial technology firms, innovation is crucial. We find on average these firms receive anywhere between 74 to 131 patents per year. Traditionally, firms have ignored these companies, firms between sic code 6000 - 6999 have been removed from these studies. However, the removal of these types of firms from previous studies provides a potential opportunity for researchers. For financial technology firms, innovation is .

In the next section, we review the literature and work that has been done investigating innovation as well as innovation in the financial technology sector. In Section 3, we discuss the data and other measures employed in this study. In Section 4, we study an overview of financial technology and 
innovation. In Section 5, we draw conclusions and suggestions for future research on the topic of financial technology.

\section{Literature Review}

The financial sector is accustoming to innovation. There is a flavor of innovation in everything the financial sector does. Much research is dedicated to the innovation that comes by way of financial engineering. For example, Merton (1995) highlights how some financial innovation has improved the functions of financial markets. However, for financial technology firms, innovation has extended beyond financial engineering.

Innovation has been found to be a primary driver of growth. For example, innovation has been found to affect managerial behavior, such as CEO overconfidence (Hirshleifer et al., 2012; Galasso and Simcoe, 2011), executive hubris (Tang, 2015), or CEO-connections (Faleye, 2014). The literature shows that adequately motivating a manger to innovation can lead to better innovation outcomes. For example, not only stimulating a manager to innovate, but also motivating a manager for a longterm growth perspective support positive innovation outcomes (Manso, 2011; Ederer and Manso, 2013). External factors, such as financial development (Hsu et al., 2014) or analysis coverage (He and Tian, 2013) have been found to affect the innovation output of firms also.

Financial technology has touched several aspects of firms. For example, Hodge et al. (2004) show how a simple switch to a searchable data structure XBRL can improve access to an individual's stock information. Blockchain, a product of financial technology, has demanded a robust argument both inside and outside the financial literature. Tapscott and Tapscott (2017) discuss some aspects of how blockchain is changing finance. In addition, the authors extensively discuss the disruption of blockchain and technologies that are similar. 
Hauswald and Marquez (2003) investigate the dual role of financial technology. They highlight the fact that technology can make access and services in the finance sector better. However, in the same manner, financial technology improves a bank's ability to process information increases interest rates and bank profits. They argue that predictions regarding financial claims' pricing hinge on the overall effect ascribed to technological progress.

Financial technology firms face unique challenges. Lee and Shin (2018) discuss additional challenges faced by startup financial technology firms. However, financial technology relies upon lower regulations. Treleaven (2017) describes how regulatory reform can provide more opportunity for fintech firms. Examples of this type of innovation include robo-advisors. The goal of robo advisors is to provide investment advice cheaply to a mass audience Sironi (2016).

For some firms, innovation can increase the likelihood of survival (Cefis and Marsili, 2006), and for others, innovation is the most efficient way to drive growth (Coad and Rao, 2008). Previous studies that have focused on innovation have removed observations related to the financial sector. However, financial firms have a distinct role to play in innovation. Our results show financial technology firms average more than 70 patents per year.

\section{Data and Descriptive Statistics}

\subsection{Patent Data}

Traditionally, researchers have measured the innovation of a firm by observing its outputs. One of the most popular measures of innovation output is patents. Patents are an attractive measure of innovation output for firms because for several reasons. Three primary reasons are as follows. First, firms are incentivized to issue a patent as a method of securing intellectual property rights. A patent, if granted, protects the firm from outside competitors seeking to create the same product. This process plays a vital role in a firm realizing a return on investment. Second, patents must reasonably describe the 
invention or creation. Lastly, several researchers have found a correlation between patent citation and patent value (Trajtenberg, 1990; and Kogan et al., 2017). In short, a patent that receives numerous citations from other patents is considered a more impactful and meaningful innovation.

To get a meaningful picture of the innovation taking place in the financial technology industry, we must first identify a link between patents and financial technology firms. However, numerous issues such as ownership changes, variations on firm names, and even simple misspellings can make this process a challenge. Researchers such as Hall et al. (2005), Lai et al. (2011), Kogan et al. (2017) have made meaningful and robust contributions; however, the last year covered by a combination of these datasets is 2010. Therefore, in this study, we extend the traditional patent data sources through a process of combination and data gathering.

The data sources of Hall et al. (2005), Lai et al. (2011), Kogan et al. (2017) are limited in term to the year 2010. Many patents have been filled and granted between 2010 and 2018, the year of this study writing. Therefore, we extend the traditional data using the following process. First, building on the foundation of Hall et al. (2005), Lai et al. (2011), Kogan et al. (2017), we begin by combining all three datasets because of their preliminary match of the patent assignee to Compustat identifier. By using the prior data, we take advantage of the robust foundational matching of prior researchers. Next, we conduct our process to match patent assignee to Compustat firm. The process involves a name standardization routine similar to that used by Hall et al. (2005) and Kogan et al. (2017). The routine focuses on the standardization of corporate names and identifiers such as changing "International" to "INT" or "Corporation" to "CORP" as well as removing unnecessary punctuation. After cleaning the data using our name standardization routine, we perform a search by hand for any missing or uncounted patents. As a result, our final data match patents to their corporate owners. 
The results of our matching provide a stable dataset of financial technology patents and their corporate owners. Table 1 displays the total number of patents as compared to the total number of firms classified as being a financial technology firm.

\section{[Table 1]}

Our patent dataset spans from 1998 to 2016. As shown in Table 1, in 1998 we identified 52 financial technology firms and 3,799 as compared to 2016 where we identify 116 financial technology firms and over 10,000 patents. While the number of firms is growing, the number of patents assigned per firm in the financial technology industry has remained relatively stable. In 1998, we found about 73 patents assigned per firm, as compared to a maximum of about 131 patents in 2001. Comparatively, the last year of our sample, 2016, nearly 92 patents are assigned per firm.

\subsection{Additional Data}

In addition to data on firm patents, we collect other relevant data to our study. We collect firm fundamental data from Compustat, such as ROA, total assets, the total number of employees, total debt, and market capitalization.

\section{Financial Innovation}

Descriptive statistics for the data collected is presented in Table 2.

\section{[Table 2]}

Table 2 displays the firm fundamental information for 120 unique firms between the years 1998 2016 inclusive. The data show that on average across the full sample, financial technology firms are awarded 84.76 patents. This level of patenting activity classifies financial technology firms as being a high innovation industry. In addition, financial technology firms have a large range of total assets with an average of 3,315.73 million and a significant standard deviation of $12,972.12$. We can see that firm 
in this industry do not have to be large, as the smallest firm in our sample has 12,000 in total assets. We find similar results for the firm's total number of employees (average of 14.25 with a standard deviation of 50.88) as well as its market capitalization (average of 5,285.19 with a standard deviation of 20,319.56). Table 3 presents the pairwise correlation between our firm fundamental variables and other patent variables.

\section{[Table 3]}

Table 3 describes the relationship between firm fundamentals and financial patents. As expected, many of the variables found to affect innovation in the literature are correlated with financial innovation. For example, Total Assets, Number of Employees, and market capitalization are all significantly positively related to the total number of financial patents. In addition, total debt and book leverage are significantly negatively related to financial technology firms receiving patents. This simple analysis delivers a straight forward result that shows that the innovation of financial technology firms is affected by the same variables as others.

[Figure 1]

In Figure 1, we show the total number of financial technology firms' overtime. Based on our classification, financial technology firms are increasing steadily over time. These results are consistent with the findings of prior research. Figure 2 shows the total number of patents issued to financial technology firms.

[Figure 2] 
Again, we find that the total number of patents is increasing over time. An interesting result we see in the years surrounding 2000 and 2006 is that the total number of innovation has decreased. This is interesting because it corresponds to the dot com bubble and the financial crisis. For many firms, this was some of the most prosperous times for firm value and innovation. The fact that we find that financial technology firms have a decreased patent output during this time is of note.

Our primary objective is to highlight the importance of financial technology. We began by showing how fintech firms create innovation. As discussed in the introduction and literature review, for all firms, innovation is important. However, in traditional studies, financial technology firms are often ignored. As the preliminary statistics show, innovation is preliminary in financial technology firms.

The research of Lee and Shin (2018) describes the challenges associated with financial technology.

One such challenge facing technology firms is data breaches. A data breach can be very harmful to a firm. When a firm experiences a data breach they have been found to affect market values (Gatzlaff and McCullough, 2010; Sen and Borle, 2015; and Goel and Shawky, 2009). In this study, we collect data breaches from Privacy Rights Clearinghouse and match them to the firms of our study. The total number of data breaches can be found in Table 4 .

\section{[Table 4]}

Examples of data breaches in our sample include 29. In our sample, the total number of breaches is relatively low. We can see that even though the number of firms is increasing steadily, the total number of data breaches remain low at 1 to 5 . Over time the total number of customers affected by data breaches also increases over time.

\section{Conclusion}


While financial technology has come a long way since the days of the ATM and computation machine, it still faces some of the same challenges. How to balance the interests of stakeholders while still maintaining healthy growth. Our results and data show that financial technology has been and continues to grow over time. However, it has not been unabated. Macro events, such as the dot com bubble and firm-specific events, such as data breaches, are still a sobering reminder of the necessary constant pace of innovation.

We show that innovation in the financial technology sector has been increasing over time as measured by patenting activity. 


\section{References:}

Cefis, E., \& Marsili, O. (2006). Survivor: The role of innovation in firms' survival. Research policy, 35(5), 626-641.

Coad, A., \& Rao, R. (2008). Innovation and firm growth in high-tech sectors: A quantile regression approach. Research policy, 37(4), 633-648.

Ederer, F., \& Manso, G. (2013). Is pay for performance detrimental to innovation?. Management Science, 59(7), 1496-1513.

El Chihimi, K. A. (2018). Fintech \& the banking industry: disruption or evolution? (Doctoral dissertation).

Fagerberg, J., \& Verspagen, B. (2006, September). Innovation studies-an emerging discipline (or what)? A study of the global network of innovation scholars. In SPRU 40th Anniversary Conference. University of Sussex. SPRU.

Faleye, O., Kovacs, T., \& Venkateswaran, A. (2014). Do better-connected CEOs innovate more?. Journal of Financial and Quantitative Analysis, 49(5-6), 1201-1225.

Galasso, A., \& Simcoe, T. S. (2011). CEO overconfidence and innovation. Management Science, 57(8), 1469-1484.

Hauswald, R., \& Marquez, R. (2003). Information technology and financial services competition. The Review of Financial Studies, 16(3), 921-948.

He, J. J., \& Tian, X. (2013). The dark side of analyst coverage: The case of innovation. Journal of Financial Economics, 109(3), 856-878.

Hirshleifer, D., Low, A., \& Teoh, S. H. (2012). Are overconfident CEOs better innovators?. The journal of finance, 67(4), 1457-1498.

Hodge, F. D., Kennedy, J. J., \& Maines, L. A. (2004). Does search-facilitating technology improve the transparency of financial reporting?. The Accounting Review, 79(3), 687-703.

Hsu, C. W., Lien, Y. C., \& Chen, H. (2015). R\&D internationalization and innovation performance. International Business Review, 24(2), 187-195.

Kogan, L., Papanikolaou, D., Seru, A., \& Stoffman, N. (2017). Technological innovation, resource allocation, and growth. The Quarterly Journal of Economics, 132(2), 665-712. 
Lee, I., \& Shin, Y. J. (2018). Fintech: Ecosystem, business models, investment decisions, and challenges. Business Horizons, 61(1), 35-46.

Manso, G. (2011). Motivating innovation. The Journal of Finance, 66(5), 1823-1860.

Merton, R. C. (1995). A functional perspective of financial intermediation. Financial management, 23-41.

Mollick, E. (2014). The dynamics of crowdfunding: An exploratory study. Journal of business venturing, 29(1), 1-16.

Schueffel, P. (2016). Taming the beast: a scientific definition of fintech. Available at SSRN 3097312.

Sironi, P. (2016). Fin'Tech innovation: from robo-advisors to goal based investing and gamification. John Wiley \& Sons.

Tang, T. W. (2016). Making innovation happen through building social capital and scanning environment. International Journal of Hospitality Management, 56, 56-65.

Tapscott, A., \& Tapscott, D. (2017). How blockchain is changing finance. Harvard Business Review, $1(9)$.

Trajtenberg, M. (1990). A penny for your quotes: patent citations and the value of innovations. The Rand Journal of Economics, 172-187.

Treleaven, P., Brown, R. G., \& Yang, D. (2017). Blockchain technology in finance. Computer, 50(9), 14-17.

Unsal, O., \& Rayfield, B. (2019). Institutional investors and medical innovation. The Quarterly Review of Economics and Finance. 
Figure 1 - Number of Firms in Our Sample by Year

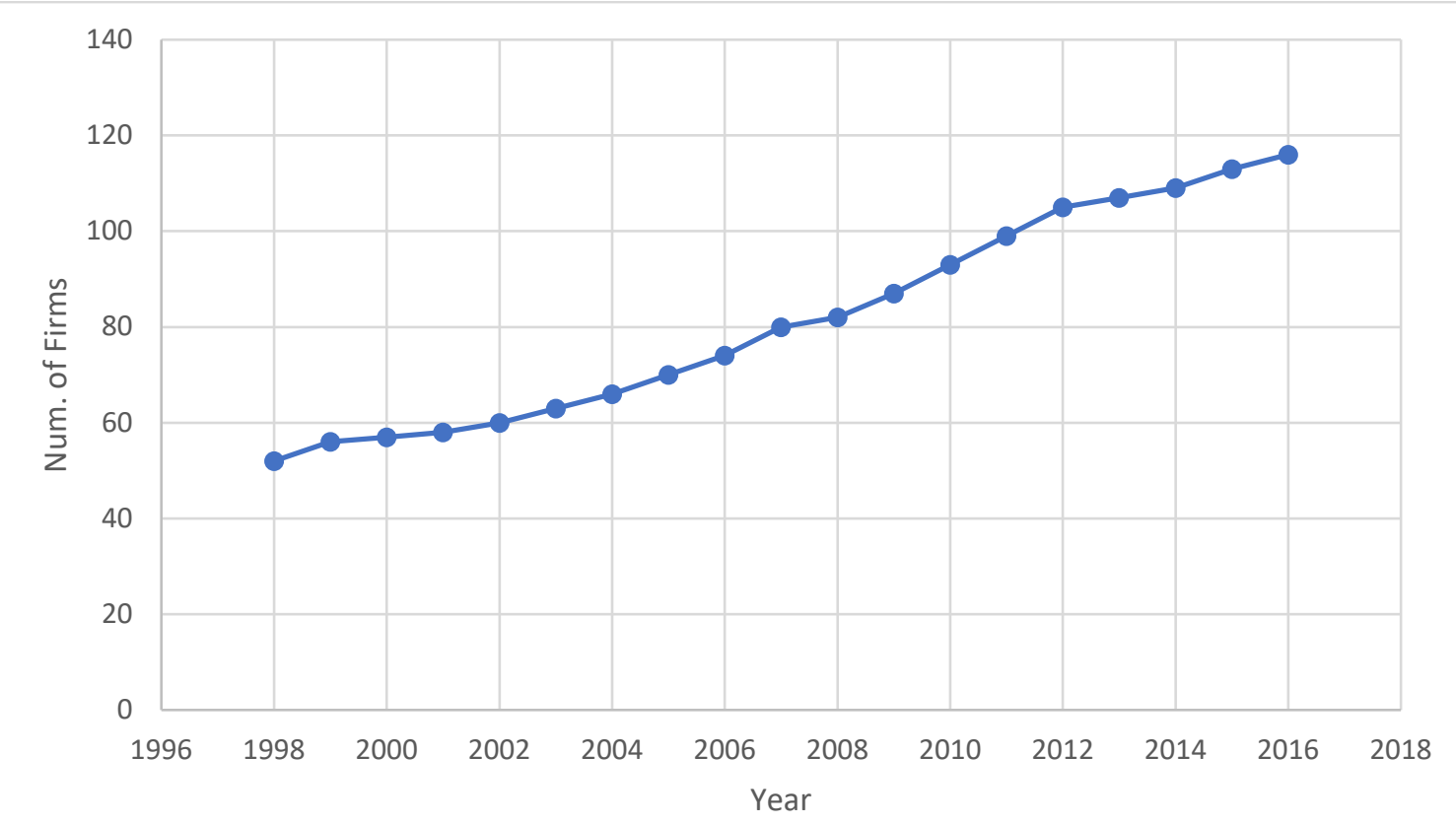

Figure 2 - Total Number of Patent by Year

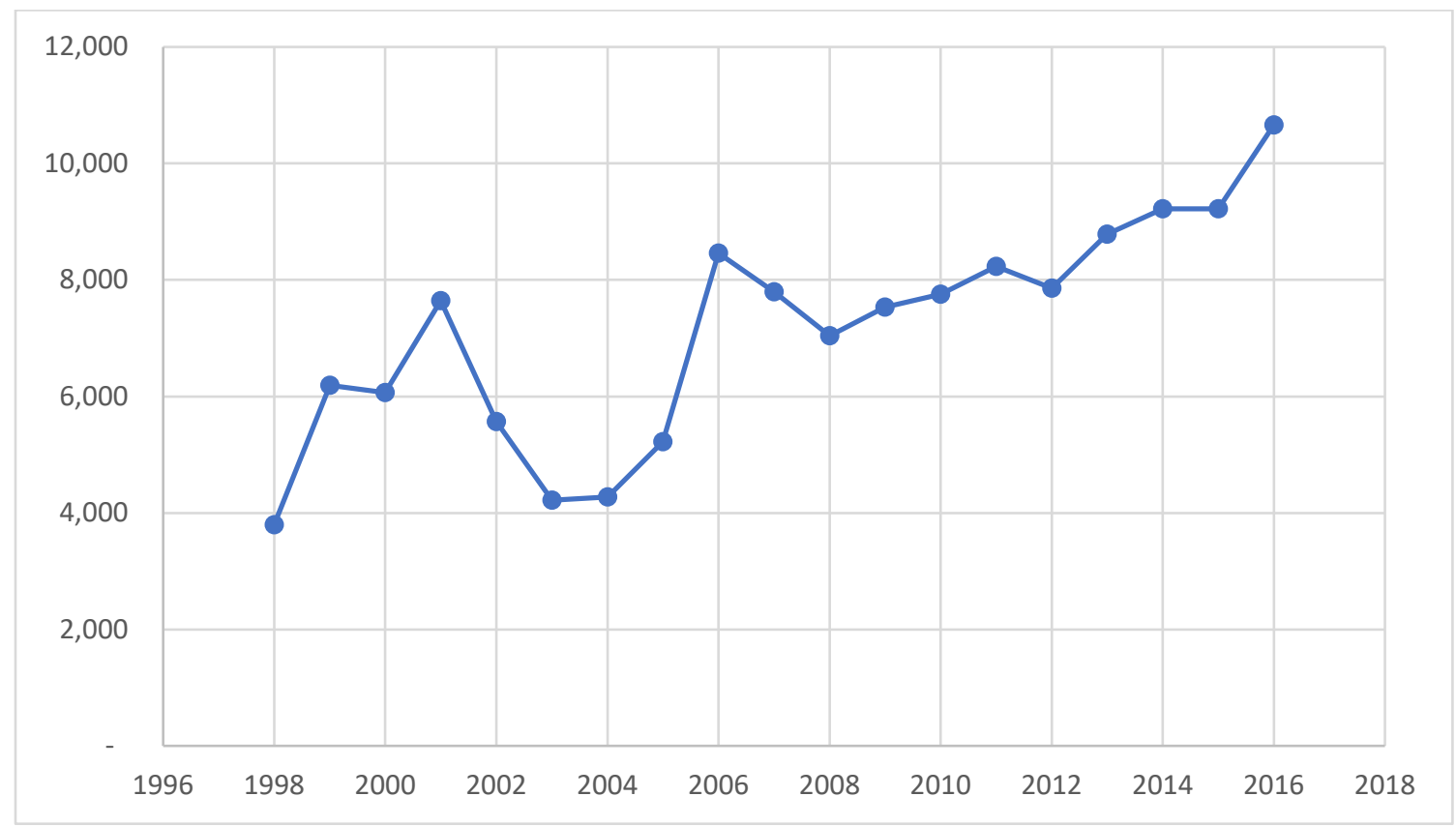


Figure 3 - Total Data Breach

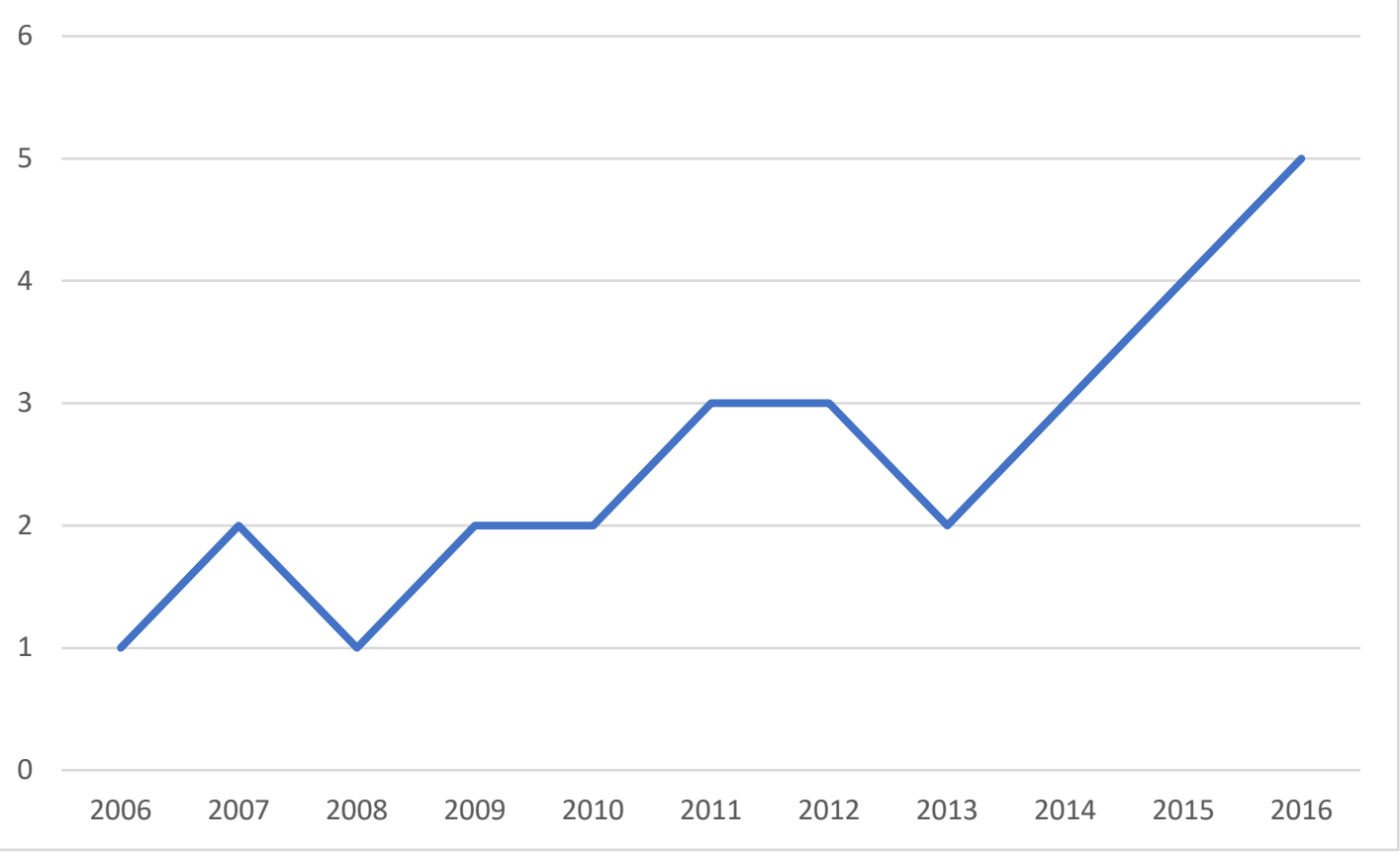

Figure 4-Number of Customer Affected

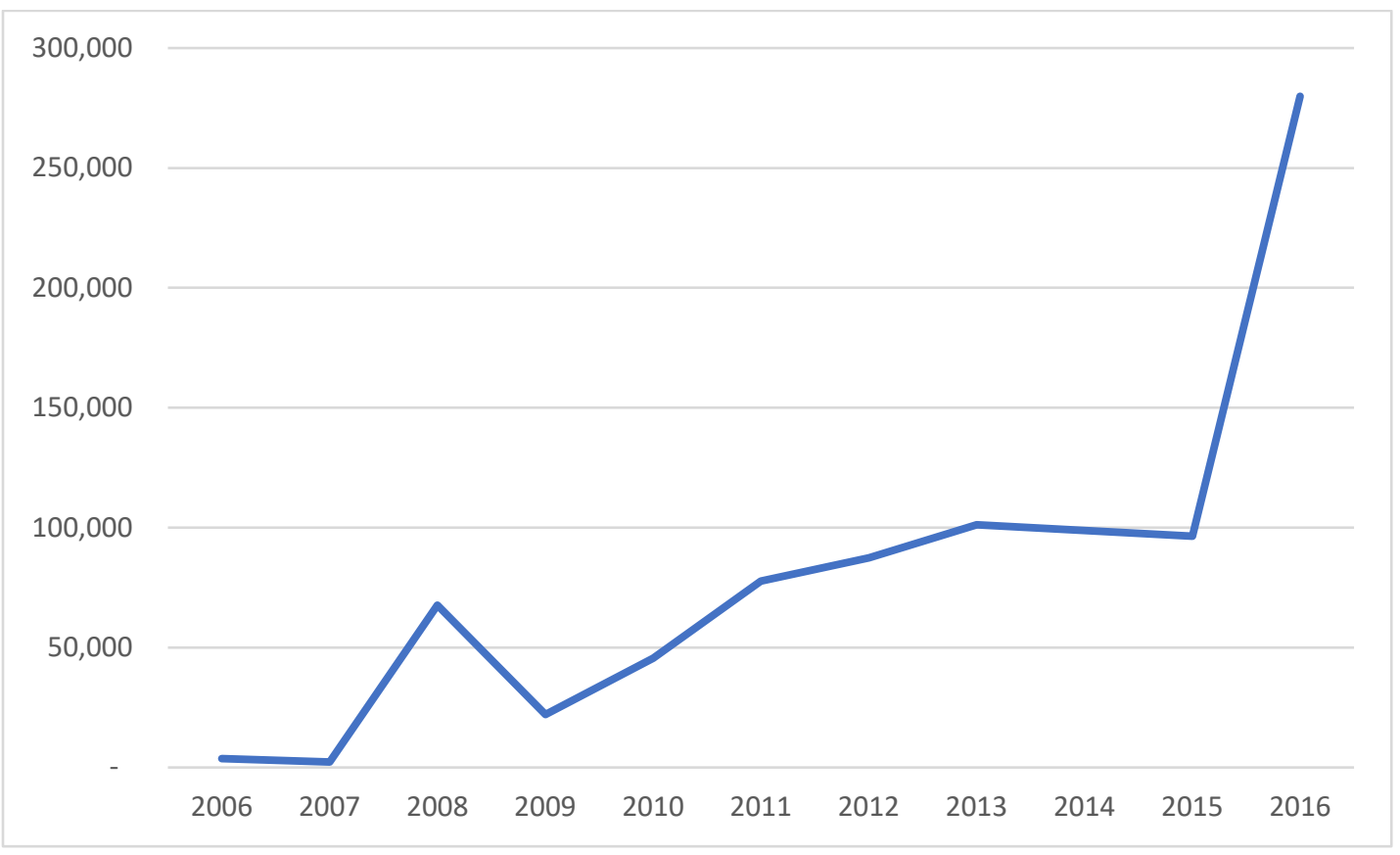


Table 1 - Number of Firms and Total Number of Patents by Year

\begin{tabular}{cccc}
\hline Year & $\begin{array}{c}\text { Num. of FinTech } \\
\text { Firms }\end{array}$ & Total Patent & $\begin{array}{c}\text { Patents Awarded Per } \\
\text { Firm }\end{array}$ \\
\hline 1998 & 52 & 3,799 & 73.06 \\
1999 & 56 & 6,188 & 110.50 \\
2000 & 57 & 6,067 & 106.44 \\
2001 & 58 & 7,643 & 131.78 \\
2002 & 60 & 5,566 & 92.77 \\
2003 & 63 & 4,219 & 66.97 \\
2004 & 66 & 4,271 & 64.71 \\
2005 & 70 & 5,221 & 74.59 \\
2006 & 74 & 8,458 & 114.30 \\
2007 & 80 & 7,797 & 97.46 \\
2008 & 82 & 7,039 & 85.84 \\
2009 & 87 & 7,536 & 86.62 \\
2010 & 93 & 7,754 & 83.38 \\
2011 & 99 & 8,229 & 83.12 \\
2012 & 105 & 7,861 & 74.87 \\
2013 & 107 & 8,787 & 82.12 \\
2014 & 109 & 9,218 & 84.57 \\
2015 & 113 & 9,221 & 81.60 \\
2016 & 116 & 10,662 & 91.91 \\
\hline
\end{tabular}

Table 1 displays the total number of financial technology firms and patents awarded to financial technology firms per year. We define financial technology firms as firms in Compustat that work in information technology, software, or research services firms, and describe themselves in their business description as working as or serving as financial institutions, banking, financial services, wealth management, finance, or payment services. 
Table 2 - Firm Level Summary Statistics

\begin{tabular}{lccccc} 
& $\mathrm{N}$ & Mean & Std. Dev. & Min & Max \\
\hline Total Financial Patent & 1,547 & 84.76 & 706.94 & 0.00 & $8,330.00$ \\
Total Fraud & 1,547 & 0.00 & 0.04 & 0.00 & 1.00 \\
Fraud Penalty & 1,547 & $76,276.66$ & $2,583,032.00$ & 0.00 & $100,000,000.00$ \\
Total Data Breach & 1,547 & 0.02 & 0.15 & 0.00 & 1.00 \\
Num. Customer Affected & 1,547 & $36,431.10$ & $4,961.00$ & 0.00 & $128,000.00$ \\
Total Assets & 1,489 & $3,318.73$ & $12,972.12$ & 0.12 & $126,223.00$ \\
Num. of Employees & 1,390 & 14.25 & 50.88 & 0.00 & 434.25 \\
ROA & 1,486 & 0.06 & 0.79 & 11.08 & 0.62 \\
Book-to- Market & 1,370 & 0.03 & 0.30 & -5.51 & 6.60 \\
Total Debt & 1,474 & 594.98 & $2,828.49$ & 1.00 & $35,075.00$ \\
Book Leverage & 1,474 & 0.15 & 0.21 & 0.00 & 3.46 \\
Tangible Assets & 1,488 & 0.08 & 0.07 & 0.00 & 0.62 \\
Market Cap. & 1,370 & $5,285.19$ & $20,319.56$ & 0.49 & $214,031.80$ \\
\hline
\end{tabular}

Table 2 displays the firm level summary statistics for financial technology firms in our sample. We collect all firm fundamental information from Compustat. Our sample consists of 120 unique firms between the years $1998-2016$ inclusive. 
Table 3 - Pairwise Correlation(s)

\begin{tabular}{|c|c|c|c|c|c|c|c|c|c|c|c|c|c|c|}
\hline & & (1) & (2) & (3) & (4) & (5) & (6) & (7) & (8) & (9) & (10) & (11) & $(12)$ & $(13)$ \\
\hline (1) & Total Financial Patent & & & & & & & & & & & & & \\
\hline$(2)$ & Total Fraud & $-0.0043^{*}$ & & & & & & & & & & & & \\
\hline (3) & Fraud Penalty & $-0.0035^{*}$ & $0.8210^{*}$ & & & & & & & & & & & \\
\hline (4) & Total Data Breach & $-0.2257^{*}$ & $0.2331 *$ & $0.1914^{*}$ & & & & & & & & & & \\
\hline (5) & Num. Customer Affected & $-0.0055^{*}$ & $0.4253^{*}$ & $0.5189 *$ & $0.4786^{*}$ & & & & & & & & & \\
\hline$(6)$ & Total Assets & $0.8649 *$ & $0.0063^{*}$ & $0.0045^{*}$ & $0.2633^{*}$ & $0.0569 *$ & & & & & & & & \\
\hline$(7)$ & Num. of Employees & $0.7695^{*}$ & -0.0088 & -0.0072 & $0.2151 *$ & $0.0496^{*}$ & $0.8714^{*}$ & & & & & & & \\
\hline (8) & $\mathrm{ROA}$ & 0.0233 & 0.0026 & 0.002 & 0.0176 & 0.006 & 0.0422 & $0.0665^{*}$ & & & & & & \\
\hline$(9)$ & Book-to- Market & -0.0108 & -0.0063 & -0.0036 & -0.0128 & -0.0061 & -0.0203 & -0.0212 & 0.0035 & & & & & \\
\hline (10) & Total Debt & $-0.8022 *$ & 0.0027 & 0.0023 & $0.2424 *$ & 0.0185 & $0.9142^{*}$ & $0.7625^{*}$ & 0.0332 & -0.0172 & & & & \\
\hline (11) & Book Leverage & $-0.0709 *$ & -0.0008 & 0.0005 & $0.1029 *$ & 0.0047 & $0.0982^{*}$ & 0.0296 & $-0.2227^{*}$ & $-0.0629 *$ & $0.2011 *$ & & & \\
\hline (12) & Tangible Assets & $0.0998^{*}$ & -0.0295 & -0.0238 & $0.0446^{*}$ & 0.0312 & $0.0496^{*}$ & $0.0910^{*}$ & $-0.0778^{*}$ & -0.0269 & 0.0286 & $0.0685^{*}$ & & \\
\hline (13) & Market Cap. & $0.8932 *$ & -0.0088 & -0.0069 & $0.2603^{*}$ & 0.0321 & $0.9508^{*}$ & $0.8941^{*}$ & 0.044 & -0.0212 & $0.8510^{*}$ & $0.0709 *$ & $0.0865^{*}$ & \\
\hline
\end{tabular}

Table 3 displays the pairwise correlation between the firm fundamental variables and financial innovation variables employed in this study. $\mathrm{A} *$ indicates significance at the 0.05 level. 
Table 4 - Data Breach and Hacking Incidents

\begin{tabular}{ccc} 
Year & Total Data Breach & Customer Affected \\
\hline 2006 & 1 & 3,695 \\
2007 & 2 & 2,284 \\
2008 & 1 & 67,755 \\
2009 & 2 & 22,112 \\
2010 & 2 & 45,544 \\
2011 & 3 & 77,666 \\
2012 & 3 & 87,461 \\
2013 & 2 & 101,221 \\
2014 & 3 & 98,866 \\
2015 & 4 & 96,443 \\
2016 & 5 & 279,888 \\
\hline
\end{tabular}

